Maurice A. Deane School of Law at Hofstra University

Scholarly Commons at Hofstra Law

Hofstra Law Faculty Scholarship

2012

\title{
A Critique of Philosophizing About Lawyers' Ethics
}

Monroe H. Freedman

Maurice A. Deane School of Law at Hofstra University

Follow this and additional works at: https://scholarlycommons.law.hofstra.edu/faculty_scholarship

\section{Recommended Citation}

Monroe H. Freedman, A Critique of Philosophizing About Lawyers' Ethics, 25 Geo. J. Legal Ethics 91 (2012)

Available at: https://scholarlycommons.law.hofstra.edu/faculty_scholarship/302

This Article is brought to you for free and open access by Scholarly Commons at Hofstra Law. It has been accepted for inclusion in Hofstra Law Faculty Scholarship by an authorized administrator of Scholarly Commons at Hofstra Law. For more information, please contact lawlas@hofstra.edu. 


\title{
A Critique of Philosophizing About Lawyers' Ethics
}

\author{
MONROE H. FREEDMAN*
}

\section{INTRODUCTION}

Prominent justices and judges have been complaining for decades that academic scholarship is irrelevant to the work of practicing lawyers and judges. That complaint is not applicable to much of the scholarship on lawyers' ethics, which has been dedicated to needed practical reform of ethical rules and practices, often to make them conform to moral norms. However, the judicial complaint is an accurate commentary on a significant body of work that has been dedicated to philosophizing about lawyers' ethics in ways that have little or no relevance to the fundamental norms and practical realities of the constitutionalized adversary system in which American lawyers function.

A principal premise of the legal ethics philosophers is that "role differentiation" is the source of all that is wrong with the ethics of practicing lawyers. The criticism is that lawyers, when acting in their professional roles, behave in ways that they themselves would otherwise condemn as a matter of ordinary morality.

Professor William Simon of Columbia University Law School is one of the most prolific and highly regarded of the ethics philosophers. I have therefore chosen Simon's most recent article on lawyers' ethics as the focus for a critique of philosophizing about lawyers' ethics. ' Simon's article begins with a hypothetical case that forms the basis for his argument that a lawyer is permitted to correct an adversary's mistake of law, to the financial detriment of the lawyer's own client, in order to bring about an outcome that the lawyer regards as consistent with ordinary morality.

By contrast, my own view is that lawyers should exercise moral discretion in deciding whether to represent a client or cause. After having made the choice to serve as the client's fiduciary, however, the lawyer is bound to zealously represent the client's interests as determined by the client after appropriate counseling by the lawyer. At that point, for a lawyer to act in a way that betrays the client's interests would be both a breach of fiduciary duty and a violation of personal moral obligations that many lawyers share.

\footnotetext{
* Professor of Law, Hofstra University Law School; Visiting Professor, Georgetown University Law Center, 2007 to present; co-author, Monroe H. Freedman \& AbBe SMith, Understanding LaWyers' Ethics, (4th ed. 2010). I am grateful for comments from Justin Hansford, Steven Lubet, Andrew Perlman, Abbe Smith, Michael Tigar, and Alice Woolley. ( 2012, Monroe H. Freedman.

1. See generally William H. Simon, Role Differentiation and Lawyers'Ethics: A Critique of Some Academic Perspectives, 23 Geo. J. LeGal EthICS 987 (2010).
} 
My criticisms of Simon's article range from his omission and misuse of legal authorities, including his reliance on partial and misinterpreted quotations, to his intentional disregard for or dismissal of facts that are of critical practical importance. My criticisms are under ten headings:

1. Simon misstates legal authority in order to create a false tradition, which, he claims, permits a lawyer to correct an adversary's mistake.

2. Simon misstates current authorities in an attempt to support his erroneous conclusion.

3. Simon ignores relevant ethical rules that would have to be abrogated or amended if his conclusion were adopted.

4. Simon erroneously relies upon the notion of the lawyer as an "officer of the court" as justification for correcting an adversary's mistake of law.

5. Simon omits a fact that would seriously complicate his analysis of ordinary morality.

6. Simon simplifies the ordinary-morality issue by making a false assumption that overlooks a critical practical fact.

7. Simon omits the lawyer's moral obligation of candor with the client.

8. Simon wrongly assumes that all lawyers would agree with his view of what ordinary morality or justice requires.

9. Simon provides no stopping point for a lawyer's duty to best "vindicate the relevant substantive norms and ... best promote fair adjudication of [a] dispute" against the interests of the lawyer's client.

10. Simon's proposal would violate the Constitution.

\section{The Problems with Simon's Hypothetical and Initial Conclusion}

To illustrate his thesis about the gap between lawyers' ethics and ordinary morality, Simon poses the following mistake-of-law problem: ${ }^{2}$

Lawyer $X$ represents the defendant, a large corporation, in a personal injury case arising from an accident in which a truck driven by one of its agents injured a pedestrian-the plaintiff. In the course of extensive negotiation, $X$ realizes that the plaintiff's lawyer is operating under a mistaken assumption about the applicable law. The plaintiff's lawyer thinks that if X proves that the plaintiff was contributorily negligent, this proof will bar the plaintiff's claim entirely. There is a high probability that $X$ can establish contributory negligence. However, a recent statute in the relevant jurisdiction replaces contributory with comparative negligence. Plaintiff's counsel is aware of the

2. Simon's problem is similar to a more complex one in Appendix B of UNDERSTANDING LAWYERs' ETHICS, headed "Taking Advantage of an Adversary's Mistake," supra note *. This appendix is the transcript of an online discussion that took place in the 1990s among three practicing lawyers and two law professors (Stephen Gillers and me). Each of us had different reactions to the issue. 
statute but mistakenly thinks that it does not apply to this case because the relevant events occurred before its enactment. In fact, the statute applies to all cases filed after its enactment, which would include this case.

Plaintiff's counsel has made an offer to settle the case on terms that $X$ believes are more favorable to his client than a fully informed lawyer would recommend to the plaintiff. That is, the offer is outside the zone of minimally probable trial outcomes (appropriately adjusted for likelihood and litigation expense) on the side that favors the defendant. $X$ is highly experienced and is confident of this judgment.

Should $X$ accept the offer without informing opposing counsel about his mistake? Assume that if $X$ put the issue to the client, the client would decide not to disclose.

Assume, further, that neither disclosure nor failure to disclose would subject $X$ to discipline or liability. On the other hand, $X$ wants to decide what to do in a principled way so that he could justify his decision. ${ }^{3}$

Simon concludes that ordinary morality compels X to tell the plaintiff's lawyer that the latter has misread the statute and that his client is entitled to considerably more of the defendant's money than the plaintiff has asked for. Thereby, Simon says, $\mathrm{X}$ would best "vindicate the relevant substantive norms and would best promote fair adjudication of the dispute." ${ }^{4}$ Simon then purports to find a duty in lawyers' ethics that would require the lawyer to make the disclosure.

\section{SIMON MISSTATES LEGAL AUTHORITY IN ORDER TO CREATE A FALSE TRADITION, WHICH, HE CLAIMS, PERMITS A LAWYER TO CORRECT AN ADVERSARY'S MISTAKE}

Simon asserts his notion that a lawyer should correct an adversary's mistake of law is consistent with what he claims is an interrupted traditional view of an adversary system. His principal support for that fundamental premise is a single, partial quotation from George Sharswood's 1860 Essay on Professional Ethics: "Counsel ... are in duty bound, to refuse to be concerned for a plaintiff in the legal pursuit of a demand, which offends his sense of what is just and right."

But Simon's omission of the rest of the quotation is misleading because its meaning is contrary to that which Simon gives it. In the same paragraph, Sharswood went on to explain:

3. Simon, supra note 1 , at $988-989$ (citing Gary Bellow \& Bea Moulton, The Lawyering Process: MATERIALS FOR ClINICAL INSTRUCTION IN ADVOCACY 586-91 (1978)).

4. Id. at 1009.

5. George Sharswood, an Essay on Professional Ethics 39 ( $2 \mathrm{~d} \mathrm{ed.} \mathrm{1860).}$ 
The courts are open to the party in person to prosecute his own claim, and plead his own cause; and although he [the lawyer] ought to examine and be well satisfied before he refuses to a suitor the benefit of his professional skill and learning, yet it would be on his part an immoral act to afford that assistance, when his conscience told him that the client was aiming to perpetrate a wrong through the means of some advantage the law may have afforded him. ${ }^{6}$

Thus, Sharswood was not suggesting that the lawyer betray the client's interests on moral grounds while continuing to represent him, but rather that the lawyer should decline or withdraw from the representation if the lawyer considers the client's cause to be unjust. Sharswood also wrote, directly contrary to Simon: "It would be going too far to say that it is ever advisable to expose the weakness of a client's cause to an adversary .... [The lawyer] is not morally responsible for the act of the party in maintaining an unjust cause ...."7

Sharswood, who has been quoted for both sides of any proposition on lawyers' ethics, also noted that the client is not "the keeper of [the lawyer's] professional conscience," and that the lawyer should not "press for an unjust judgment."" As discussed above, however, Sharswood was referring to declining the representation or withdrawing from it. As he said, if a lawyer is compelled to "defeat what he believes to be an honest and just claim, by insisting upon the slips of the opposite party" or by "any other means than a fair trial on the merits in open court," he "ought to throw up the cause, and retire from all connection with it ...." Also, Sharswood suggests, "[the lawyer] has an undoubted right to refuse a retainer, and decline to be concerned in any cause, at his discretion." 10 Nowhere does he argue, however, that the lawyer should secretly correct the slips of the opposite party. As shown above, he says the opposite.

Moreover, Sharswood also asserts, in language worthy of Lord Brougham, who personifies zealous advocacy, ${ }^{11}$ that a "truly conscientious practitioner" has a "moral responsibility" to give "[e]ntire devotion to the interest of the client, warm zeal in the maintenance and defense of his rights, and the exertion of his utmost learning and ability."12 Thus, according to Sharswood, it is ethically proper for a lawyer to delay the recovery of an admittedly just claim against his client as long as possible by interposing every delay that the law allows ${ }^{13}$-a

6. Id. at $39-40$.

7. Id. at 20,27 .

8. Id. at 40 (quoting Rush v. Cavenaugh, 2 Pa. 187, 189 (1845) (Gibson, C.J.)).

9. George SHARswood, AN Essay on Professional Ethics 42 ( $2 \mathrm{~d}$ ed. 1860) (emphasis added).

10. Id. at 28 (emphasis added).

11. Henry Lord Brougham is the model for zealous advocacy. See Monroe H. Freedman, Henry Lord Brougham, Written by Himself, 19 GEO. J. LEGAL ETHICS 1213 (2006); see also Monroe H. Freedman, Henry Lord Brougham and Zeal, 34 HoFsTRA L. REV. 1319 (2006).

12. Sharswood, supra note 5 , at 24 . He added that a lawyer owes these duties to the client with "immovable fidelity" and "unshaken fidelity." Id. at 61, 64 .

13. Id. at 60 . 
tactic that commonly results in a settlement for less than what the claim is worth.

In short, Sharswood's position in those passages is the same as mine-that lawyers should exercise moral discretion in choosing whether to represent a client or cause-but that, in the course of representing a client, the lawyer should zealously advance the client's lawful and ethical interests as determined by the client, unless there are legitimate grounds for withdrawal without disproportionate, adverse effect on the rights of the client. ${ }^{14}$

Moreover, Sharswood wrote: "When a client employs an attorney, he has a right to presume, if the lawyer be silent on the point, that . . . he has no interest which may ... endanger his fidelity." 15 Thus, "[u]nder all circumstances, the utmost candor should be used towards the client." 16 Yet contrary to those passages, and contrary to ordinary morality, Simon advocates that a lawyer should be less candid with his own client than he would be with his adversary.

Finally, even if Sharswood's essay supported Simon's view, Simon offers no evidence that such a view was widely shared at the time. Surely, if one is trying to establish a "tradition," it should rest on more than one passage, in one essay, by one person.

\section{SIMON MISSTATES CURRENT AUTHORITIES IN AN ATTEMPT TO SUPPORT HIS ERRONEOUS CONCLUSION}

Simon refers to the fact that the bar's confidentiality rules protect "all information relating to the representation" of a client but claims that this rule is "invariably interpreted to exclude" information about legal authority. ${ }^{17} \mathrm{He}$ adds that "[n]o one doubts, for example, that $\mathrm{X}$ would be free to advise someone in an unrelated matter about the comparative negligence statute without his client's permission."18 However, Simon does not acknowledge that the "unrelated matter" is not, as he suggests, simply one example of the exception, but the full extent of it.

In support of his contention that the mistake-of-law exception should be broad, Simon cites the New York Rules of Professional Conduct. According to these Rules, "[c]onfidential information does not ordinarily include (i) a lawyer's knowledge or legal research or (ii) information that is generally known . . . in the

\footnotetext{
14. Freedman et AL., supra note *, at $\S \S 3,4.02$, app. b (Lexis $3 d$ ed. 2004); Monroe H. Freedman, The Lawyer's Moral Obligation of Justification, 74 TEx. L. REv. 111 (1995). I do not understand Simon's point to be that his duty would apply only to corporations, and not to individuals. In any event, it is unlikely that I would have chosen to represent Simon's hypothetical corporation (although I have recently represented two corporations that were, in effect, my daughter and my brother). Note that even large corporations are associations of individuals, which are protected as such under the First Amendment.

15. Sharswood, supra note 5, at 53-54.

16. Id. at 50-51.

17. Simon, supra note 1, at 989.

18. Id. (emphasis added).
} 
trade, field or profession to which the information relates." ${ }^{19}$ The Reporter for the New York Rules, Professor Roy Simon, has explained that provision in his authoritative work, Simon's New York Rules of Professional Conduct Annotated. Under the heading, "What is Not 'Confidential Information,"' Roy Simon makes the common-sense point: "[N]o one ever thought that a client could say to a lawyer, 'Don't use any of your legal research or any of your knowledge of my industry in any other case-keep it all inviolate.' If lawyers could not use industry knowledge in later cases, lawyers could not specialize." 20 Thus, William Simon receives no support for his contention that under New York ethical rules and the Restatement, a lawyer is permitted to use knowledge and research against a current client, as distinguished from using that research and knowledge in a different matter. ${ }^{21}$

William Simon also relies on a similar exception in the Restatement of the Law Governing Lawyers to support his contention that a lawyer can ethically inform an adversary about a mistake of law. However, according to the Restatement's "Information concerning law, legal institutions, and similar matters":

During legal research of an issue while representing a client, a lawyer may discover a particularly important precedent... that is useful both in the immediate matter and in other representations. The lawyer ... may use and disclose that information in other representations .... A lawyer may use such information-about the state of the law . . - in a future, otherwise unrelated representation that is adverse to the former client. ${ }^{22}$

There is no support, therefore, either in the New York Rules or in the Restatement, for Simon's contention that the confidentiality rule is "invariably interpreted" in a way that would permit a lawyer to disclose her knowledge of the law to a client's adversary in the same case, when doing so would be contrary to the interests of the client in that very case.

Finally, Simon refers to the Progressive period during the twentieth century and the idea of Purposivism as a continuation of his "interrupted tradition." However, Simon fails to provide a single quotation in which a Progressive philosopher made any reference to a duty to reveal an adversary's mistake of law, leaving his contention devoid of any textual support.

19. N.Y. RULES OF PROF'L CONDUCT Rule 1.6(a)(3) (2011).

20. Roy Simon, Simon's New York Rules of Professional Conduct ANNotated 86 (2009) (emphasis added).

21. Also, an irony here is that if a lawyer could ignore legal research that she has done on behalf of one client, and bill the next client for the time required to do the same research anew, there would undoubtedly be a justifiable outcry from the keepers of lawyers' morality regarding the overbilling.

22. Id. (emphasis added). 


\section{SIMON IGNORES RELEVANT ETHICAL RULES THAT WOULD HAVE TO BE ABROGATED OR AMENDED IF HIS CONCLUSION WERE ADOPTED}

Simon does not face up to the fact that this course of action by $\mathrm{X}$ would violate ethical rules that are consistent with ordinary morality and that, in any event, are not likely to be changed. Indeed, he incorrectly claims that his hypothetical case is "representative of ... a broad category - the category of cases that are not governed by rules ...."23

One relevant rule that Simon ignores forbids a lawyer to limit the scope of representation unless the limitation is reasonable and the client gives informed consent. ${ }^{24}$ Other rules forbid conduct involving misrepresentation, which can include failure to correct a known misunderstanding about the lawyer's role on the part of one who does not yet have a lawyer (as the client does not when contemplating whether to retain $\mathrm{X}$ ). ${ }^{25}$ Similarly, other rules require the lawyer to inform the client promptly of any decision or circumstance that requires the client's informed consent, ${ }^{26}$ and to keep the client reasonably informed about the status of the matter ${ }^{27}$ Consistent with ordinary morality, Comment 5 to Model Rule 1.4 explains: "[t]he client should have sufficient information to participate intelligently in decisions concerning the objectives of the representation and the means by which they are to be pursued .... In litigation a lawyer ... ordinarily should consult the client on tactics that are likely to result in significant expense ...."28 We do not learn whether Simon would simply abrogate these rules (because he claims that no relevant rules exist) or, alternatively, whether he would amend them and, if so, how he would do so.

\section{SIMON ERRONEOUSLY RELIES UPON THE NOTION OF THE LAWYER AS AN "OFFICER OF THE COURT" AND UPON A PURPORTED OBLIGATION TO DISCLOSE CLIENT PERJURY TO THE COURT, AS AUTHORITIES FOR CORRECTING AN ADVERSARY'S MISTAKE OF LAW}

Simon is apparently unaware that there has never been a meaningful obligation to disclose client perjury in the entire history of legal ethics. This supposed obligation has been wholly ineffectual-as intended-except in some cases involving indigent criminal defendants represented by court-appointed law-

23. Simon, supra note 1, at 1006 . Early in his article, Simon makes passing reference to some ethical rules, but provides no analysis of them.

24. Model Rules of Prof'l Conduct R. 1.2(c) (2009) [hereinafter Model Rules]. Simon might say that his limitation is "reasonable," a contention that he purports to support by citing an "interrupted tradition" in lawyers' ethics. Since he fails to establish his claim of an interrupted tradition, however, his definition of "reasonable" is supported only by his own idiosyncratic view, contrary to all tradition, and with no support at all in legal ethics authorities.

25. See Model Rules R. 4.3; Model Rules R. 8.4(c).

26. Model Rules R. 1.4(a)(1); Model Rules R. 1.0(e).

27. Model RULes R. 1.4(a)(3).

28. Model Rules R. $1.4 \mathrm{cmt} .5$. 
yers. ${ }^{29}$ Not surprisingly, therefore, the three cases that Simon cites to establish such an obligation are all cases involving indigent defendants. ${ }^{30}$

Moreover, Simon incorrectly cites People v. Cox as a case in which a court relied on the idea of the lawyer as an "officer of the court" to allow disclosure of a client's confidence. ${ }^{31}$ In fact, the court in Cox said nothing itself about the lawyer as an officer of the court-it was the court-appointed defense lawyer, not the court, who had justified her disclosure of her client's perjury on the ground that she was an officer of the court. ${ }^{32}$

In any event, Simon is unclear about how he is using the notion of the lawyer as an "officer of the court." First, he invokes it as a "core principle of professional responsibility," 33 but he later says that his argument is not that this core principle "entails disclosure [of a mistake of law] in the categorical sense." ${ }^{34}$ Rather, it imposes a "responsibility to take account of indications that injustice is likely to occur if the lawyer adheres to the presumption of partisanship."35

Whatever that means, the American Bar Association pointed out, in 1953 (during the Progressive period to which Simon attributes a continuation of his "tradition" that would require disclosure) ${ }^{36}$ that the idea of the lawyer as an officer of the court begs the question of what a lawyer is required to do in particular situations. Discussing disclosure of client perjury (the context in which Simon raises the idea of the lawyer as an officer of the court), the ABA Committee on Professional Ethics wrote:

We yield to none in our insistence on the lawyer's loyalty to the court of which he is an officer. Such loyalty does not, however, consist merely in respect for the judicial office and candor and frankness to the judge. It involves also the steadfast maintenance of the principles which the courts themselves have evolved for the effective administration of justice, one of the most firmly established of which is the preservation undisclosed of the confidences communicated by his clients to the lawyer in his professional capacity. ${ }^{37}$

29. Monroe H. Freedman, Getting Honest About Client Perjury, 21 Geo. J. Legal Ethics 133, 135 (2008); FREEDMAN et al., supra note *, at $\S 6$.

30. Simon, supra note 1, at 1001 n.30. With regard to Nix v. Whiteside, 457 U.S. 157 (1985), see FreEDMAN ET AL., supra note *, at 170-184. With regard to People v. DePallo, 754 N.E.2d 751 (N.Y. 2001), see FrEEDMAN ET AL., supra note *, at 160-161.

31. Simon, supra note 1, at 1001 n.30 (incorrectly citing People v. Cox, 809 P.2d 352, 368 (Cal. 1991)).

32. See Cox, 809 P.2d at 366.

33. Simon, supra note 1 , at 1001 .

34. Id. at 1002.

35. Id.

36. Id. at 1008.

37. ABA Comm. on Prof'l Ethics \& Grievances, Formal Op. 287 (1953); see also FreEDMAN ET AL., supra note *, at 9 (citing similar views in the U.S. Supreme Court with regard to the lawyer as an officer of the court). E.g., In re Griffiths, 413 U.S. 717, 724 (1973) (referring to the lawyer's "honored and traditional role as an authorized but independent agent acting to vindicate the legal rights of a client. ..."). 
That is, as an officer of the court, the lawyer is required to put the obligation of confidentiality above the obligation of candor with the court.

Thus, Simon is left with no "interrupted tradition" and no authority whatsoever for his contention that the adversary system formerly incorporated a duty that a lawyer disclose mistakes of law to the disadvantage of a client.

\section{SIMON OMITS A FACT THAT WOULD SERIOUSLY COMPLICATE HIS ANALYSIS OF ORDINARY MORALITY}

When a lawyer agrees to represent a client, the lawyer will have made a promise-in other words, she will have expressly or impliedly given her word, upon which the client can be expected to rely, that she will use all lawful and ethical means that are reasonably available to advance the client's lawful interests in carrying out the representation. Clients generally rely upon this assumption when they enter a lawyer-client relationship. ${ }^{38}$ However, as discussed in the preceding section, Simon would have the lawyer accept the client's retainer without requiring the lawyer to disabuse the client of this belief.

Promises, of course, are generally recognized as among the heaviest of obligations of ordinary morality. For example, for Immanuel Kant, keeping promises is an essential aspect of the categorical imperative. ${ }^{39}$ When other practicing lawyers and I insist upon client-centered representation, we are relying upon ordinary morality as well as our own sense of personal morality-that is, our obligation to keep our word to our clients. When Simon and other moral philosophers omit the fact of the lawyer's promise to the client in discussing the role of morality, they falsely distort the moral analysis.

\section{SIMON SIMPLIFIES THE ORDINARY MORALITY ISSUE BY MAKING A FALSE ASSUMPTION THAT AVOIDS A CRITICAL PRACTICAL FACT}

Simon's hypothetical includes the following assumption, thereby omitting a critical issue that $X$ and his firm would face in actual fact: "Assume," Simon writes, "that neither disclosure nor failure to disclose would subject $\mathrm{X}$ to discipline or liability." ${ }^{\prime 40}$ Yet this assumption overlooks a critical issue that $\mathrm{X}$ and his firm would face in actual fact.

\footnotetext{
38. The exceptions are clients of court-appointed lawyers, who frequently do not trust their lawyers; too often, this distrust is for good reason.

39. Immanuel Kant, Groundwork of the Metaphysics of Morals, in KANT SELECTIONS 268, 310 (Theodore Meyer Greene ed., Thomas Kingsmill Abbott, trans., 1929); Thomas HobBes, LeViathan 202 (C.B. Macpherson ed., 1968) ("But when a Covenant is made, then to break it is Unjust: And the definition of INJUSTICE, is no other than the not Performance of Covenant."); see also JOHN LOCKE, AN EsSAY CONCERNING HuMAN UNDERSTANDING 27 (1909) ("Justice, and keeping of contracts, is that which most men seem to agree in.").
}

40. Simon, supra note 1 , at 988 . 
I have advised lawyers in a considerable number of matters in resolving ethical problems that have included the potential for disciplinary action and malpractice liability. Namely, the lawyers had a reasonable concern with whether they might lose their licenses to practice law, face liability that might destroy their firms, and/or cause each lawyer in the firm enormous personal liability that could result in the loss of the ability to provide adequately for the welfare of his or her family. ${ }^{41}$ This is both a highly practical concern as well as one that is relevant to ordinary morality. ${ }^{42}$

Furthermore, even if one were to agree with Simon that ordinary morality would require the defendant corporation, which was responsible for the plaintiff's injuries, to be fully responsible for his loss, that does not end the moral analysis. Many would nevertheless hold that ordinary morality does not require $\mathrm{X}$ and the individual members of his firm to be fully liable financially for the plaintiff's injuries. Yet that would be the result if X's client sued X, his firm, and each of the partners individually in a malpractice suit for having increased the client's liability. In short, contrary to Simon's assumption, the client ultimately would not pay for its wrongdoing-X, his firm, and his partners would pay for the corporation's wrongdoing instead.

Simon might respond that he shows in his article that the lawyer has a duty to inform the adversary, so there would be no malpractice or disciplinary action. However, the existence of such a duty would not prevent a malpractice or disciplinary action, and no one would want to undergo the expense and anxiety of having to mount a defense, even one that is ultimately successful. ${ }^{43}$ More importantly, as shown above, Simon has not cited a single authority that supports his assertion that there is such a duty, and he has ignored or mischaracterized several authorities that are directly contrary to his thesis. ${ }^{44}$

\section{SIMON OMITS THE MORAL OBLIGATION TO HAVE CANDOR WITH THE CLIENT}

Without thoroughly addressing the problem raised in the preceding section, Simon in effect anticipates it in his hypothetical by relying on another highly questionable assumption, which he fails to justify. Simon assumes that $\mathrm{X}$ can

\footnotetext{
41. See FreEdman ET Al., supra note *, at $\$ 4.03$.

42. See id. at 72 ("Supporting oneself and one's family is a moral obligation.").

43. A lawyer who told opposing counsel the amount that the firm's client was willing to accept in settlement was ordered to compensate the client for its loss, and was suspended from practice for thirty days. In re Neil Daniel O'Connor, M.R. 19328, 01 CH 96 (Ill. May 17, 2004). Simon might say that he intended to show only that the authorities are ambiguous regarding the obligation to correct an adversary's mistake of law. Apart from the fact that he has failed even to do that, an ambiguity about applicable law would virtually guarantee a malpractice action against Lawyer X and his firm. Also, see note 46, infra, quoting Simon's assertion that his argument is that there is, in fact, a duty to disclose, and not that the authorities are ambiguous on the issue.

44. Simon incorrectly claims that his hypothetical case is "representative of . . a broad category-the category of cases that are not governed by rules...." Simon, supra note 1, at 1006.
} 
lawfully and ethically conceal from his client the fact that he is acting in a way that is contrary to the client's lawful interests. This is inconsistent not only with ordinary morality but also with ethical rules and malpractice law, none of which Simon addresses in this context.

Simon writes: "Assume that if $\mathrm{X}$ put the issue to the client, the client would decide not to disclose." 45 Note that Simon does not write: "Assume that when X puts the question to the client, the client decides not to disclose." Thus, Simon can assume that $X$ and his law firm will not face disciplinary action or financial liability because he posits in his article that $X$ properly can and will conceal this important information from the client. Simon has subsequently confirmed this reading online. ${ }^{46}$

There is a particular irony here. Simon champions honesty and candor with a client's adversary on moral grounds, but he is willing to allow the lawyer to hoodwink his own client. This takes place at two important points. First, when the client is considering whether to retain $X$, Simon will not require that $X$ tell the potential client at the outset that he will favor the interests of the client's adversary over the interests of the client if that is what X's sense of justice tells him to do. This is contrary to the understanding that virtually all clients hold when retaining a lawyer. Second, Simon will not require $\mathrm{X}$ to tell the client that he is giving legal advice to the adversary's lawyer, which will increase the damages that the client would otherwise have to pay. Rather, he will allow the lawyer to betray the client's interests and then continue to represent, and to bill, the unsuspecting client.

\section{SIMON INDULGES THE FALLACY THAT ALL LAWYERS WOULD AGREE WITH HIS VIEW OF WHAT ORDINARY MORALITY OR JUSTICE REQUIRES}

Simon and other moral philosophers assume that all lawyers would resolve questions of ordinary morality and justice in a manner consistent with their own moral sense ${ }^{47}$-in Simon's hypothetical, for example, the judgment that the defendant corporation should be fully responsible financially for the plaintiff's injuries. Incidentally, I have been corresponding recently with a lawyer who

\footnotetext{
45. Id. at 988 (emphasis added).

46. Bill Simon, Does the lawyer have to tell the client when she helps out the other side?, LEGAL ETHICS ForUM (Jan. 25, 2011, 5:47 PM), http://www.legalethicsforum.com/blog/2011/01/bill-simon-asks-does-thelawyer-have-to-tell-the-client-when-she-helps-out-the-other-side.html. Simon wrote:
}

[T] he main theme of my argument in the article was that the lawyer does have a duty to disclose there. If I am correct about that, the objection about client disclosure is wrong. There's no duty for the lawyer to disclose where the client has no right to make a decision on the matter and where he could not make any legitimate use of the information.

Id. As shown above, however, Simon has failed to establish any authority for his premise that the lawyer has a duty of disclosure to his client's adversary in his hypothetical.

47. See, e.g., Monroe H. Freedman, How Lawyers Act in the Interests of Justice, 70 FORDHAM L. REV. 1717, 1724-1727 (2002). 
believes that it is morally wrong and contrary to public policy to hold Exxon liable for the oil spill off Alaska or to make BP pay anything for the oil spill in the Gulf of Mexico. I disagree with that lawyer on that issue, as I am sure Simon does, but other lawyers agree with my correspondent. Of course, additional illustrations could be provided. ${ }^{48}$

More importantly, the assumption that lawyers are more moral than their clients, and therefore should act as a moral oligarchy to override the client's lawful and ethical objectives, is both patronizing and arrogant.

\section{SIMON PROVIDES NO STOPPING POINT FOR A LAWYER'S DUTY TO BEST "VINDICATE THE RELEVANT SUBSTANTIVE NORMS AND . . BEST PROMOTE FAIR ADJUDICATION OF [A] DISPUTE" AGAINST THE INTERESTS OF THE LAWYER'S CLIENT ${ }^{49}$}

Assuming that there is any duty of the kind that Simon proposes, where does it stop? Would a defendant's lawyer have a duty to advise an aggrieved person's lawyer that the statute of limitations is about to run on the potential plaintiff's claim, or that the plaintiff's lawyer has neglected to include a viable cause of action in the Complaint, or that punitive damages should have been claimed? Should a plaintiff's lawyer have a duty to advise the defendant's lawyer that the Statute of Frauds should have been pleaded in the Answer? Should Trial Lawyer $\mathrm{X}$ tell Trial Lawyer $Y$ that $X$ 's question to a witness could be blocked by a hearsay objection?

If these questions look silly, it is because they are. But I cannot see why they fall outside of Simon's supposed duty to do what each lawyer conceives of as justice in the case, irrespective of the interests of the client who is relying upon the lawyer for legal representation.

\section{SIMON'S PROPOSED DUTY WOULD VIOLATE THE CONSTITUTION}

I am not aware of a single article in which Simon or any other philosophical ethicist has confronted the question of whether their proposals are constitutionally valid. For example, the Supreme Court has written:

If in any case, civil or criminal, a state or federal court were arbitrarily to refuse to hear a party by counsel, employed by and appearing for him, it reasonably may not be doubted that such a refusal would be a denial of a hearing, and, therefore, of due process in the constitutional sense..$^{50}$

\footnotetext{
48. See id.

49. Simon, supra note 1 , at 1009.

50. Powell v. Alabama, 287 U.S. 45, 69 (1932). Thus, it was a violation of the Sixth Amendment right to counsel when the trial court denied the defendant the right to be represented by his first choice of counsel, regardless of whether he had received a fair trial in accordance with due process while thereafter represented by
} 
Elsewhere, Justice Stevens has noted that "the litigant's freedom to choose his own lawyer in a civil case is a fundamental right,"51 and Justice Brennan has called this right "a fundamental premise of the adversary system."

In explaining what this right to counsel means, the Court has held that a lawyer "must take all reasonable lawful means to attain the objectives of the client." 53 Accordingly, the Fifth Circuit has held that the right to counsel includes consultation between lawyer and client. ${ }^{54}$ In that civil case, the court held that the trial judge had violated the Constitution by prohibiting a lawyer from communicating with his client during a break in the client's testimony.

With regard to Simon's hypothetical, these authorities suggest that the defendant's lawyer would violate his client's right to counsel by failing to consult with the defendant about how he might achieve his lawful objective of paying no more than what the plaintiff had been demanding. ${ }^{55}$ Regardless of how this issue would be resolved, however, it is a subject that should be confronted in any proposal for a radical change in traditional legal representation.

\section{CONCLUSION}

In the world of real lawyers and real clients, "role differentiation" refers to a fiduciary relationship in which the lawyer promises to take all reasonable and lawful means to attain the objectives of the client. This promise is an inescapable part of any meaningful moral analysis. Also, lawyers function under ethical rules, many of which reflect ordinary morality, and violation of those rules can result in serious professional sanctions and malpractice liability. Those rules and that potential responsibility should not be ignored in proposals for radical changes in how lawyers serve their clients. In addition, lawyers in the United States are subject to a constitutionalized adversary system, which defines and limits their professional responsibilities in fundamental respects. ${ }^{56}$ When moral philosophers ignore these practical concerns, they produce articles and books that have no significance in the world of real lawyers and real clients. As Chief Justice Roberts

his second choice of counsel. See United States v. Gonzalez-Lopez, 548 U.S. 140, 148 (2006); see also Note, The Right to Counsel in Civil Litigation, 66 CoLum. L. Rev. 1322 (1966).

51. Richardson-Merrell, Inc. v. Koller, 472 U.S. 424, 442 (1985) (Stevens, J., dissenting).

52. Id. at 441 (Brennan, J., concurring).

53. Nix, 475 U.S. at 166 (1986). Simon might say that correcting an adversary's mistake of law is "reasonable," a contention that he purports to support by citing an "interrupted tradition" in lawyers' ethics. Since he fails to establish his claim of an interrupted tradition, however, his definition of "reasonable" is supported only by his own idiosyncratic view, contrary to all tradition, and with no support whatsoever.

54. Potashnick v. Port City Constr. Co., 609 F.2d 1101 (5th Cir. 1980).

55. In effect, the client would be deprived of his or her property without the fair process of notice and an opportunity to be heard. See Fuentes v. Shevin, 407 U.S. 67 (1972).

56. See FREEDMAN ET AL., supra note *, at $\S 2$. 
recently observed: "What the academy is doing . . is largely of no use or interest to people who actually practice law." 57

Structural engineers do not debate whether using skyhook cables that drop magically from the sky would be a better way of building bridges than the present suspension method. Nor do they publish reply articles about how air traffic would have to be rerouted to avoid the non-existent sky hook cables. In a similar sense, philosophical theorizing about lawyers' ethics, based upon unrealistic facts and the omission of critical authorities, is irrelevant to the real-life concerns of lawyers and is a waste of scholarly effort.

My point is not that the rules of lawyers' ethics do not demand serious reform from a moral perspective. ${ }^{58}$ On the contrary, more practical moral criticism is badly needed. One of the reasons for my impatience with the work of the philosophical ethicists is that their moral sensitivity and keen intellects could be used to bring about much needed improvement in the ethics and practice of lawyers and judges.

57. Adam Liptak, Keep Those Briefs Brief, Literary Justices Advise, N.Y. Times, May 21, 2011, at Al2. Justice Samuel Alito has recently made similar criticisms. Samuel Alito, Let Judges Be Judges, MaNHATTAN INSTTIUTE FOR POLICY RESEARCH (Oct. 13, 2010) http://www.manhattan-institute.org/html/wl2010.htm. Second Circuit Judge Roger J. Miner has recently complained of the "disconnect between the professoriate and the practicing bar." Roger J. Miner, A Significant Symposium, 54 N.Y.L. SCH. L. Rev. 15, 18 (2009/2010) (citing Harry T. Edwards, Another "Postscript" to "The Growing Disjunction Between Legal Education and the Legal Profession," 69 WASH. L. Rev. 561 (1994)).

58. See, e.g., Monroe Freedman, The Influence of the American Lawyers' Code of Conduct on ABA Rules and Standards, 38 Hofstra L. Rev. 927 (2010); Monroe Freedman, The Cooperating Witness Who Lies-A Challenge to Defense Lawyers, Prosecutors, and Judges, 2 OнIо ST. J. CRIM. L. 739 (2010); Monroe Freedman, What Ever Happened to the Search for Truth?, 60 MERCER L. Rev. 851 (2009); Monroe Freedman, Getting Honest About Client Perjury, 21 Geo. J. Legal EthICs 133 (2008); Monroe Freedman, Judicial Impartiality in the Supreme Court-The Troubling Case of Justice Stephen Breyer, 30 OKL.A. CITY U. L. REv. 513 (2007); Monroe Freedman, Duck-Blind Justice: Justice Scalia's Memorandum in the Cheney Case, 18 Geo J. LegaL EtHics 229 (2004); Monroe Freedman, An Ethical Manifesto for Public Defenders, 39 VAL. U. L. Rev. 911 (2005); Monroe Freedman, The Professional Obligation to Raise Frivolous Issues in Death Penalty Cases, 31 Hofstra L. REv. 1167 (2003); Monroe Freedman, Ethics, Truth, and Justice in Criminal Litigation, 68 FoRDHAM L. REv. 1371 (2000); Monroe Freedman, Caveat Lector: Conficts of Interest of ALJ Members in Drafting the Restatements, 26 HoFstRA L. REv. 641 (1998); Monroe Freedman, The Ethical Danger of "Civility" and "Professionalism," 6 CRIM. Just. J. 17 (1998); Monroe Freedman, The Life-Saving Exception to Confidentiality: Restating the Law Without the Was, the Will Be, or the Ought to Be, 29 LoY. L.A. L. Rev. 1631 (1996); Monroe Freedman, The Threat to Judicial Independence by Criticism of Judges - A Proposed Solution to the Real Problem, 25 HofsTRA L. Rev. 729 (1997); Monroe Freedman, Ethical Ends and Ethical Means, $41 \mathrm{~J}$. LEGAL EDuC. 55 (1991); Monroe Freedman, The Need for a Rule 11 for Judges, 128 F.R.D. 409, 437-441 (1990) (delivered at the plenary session of the Seventh Annual Judicial Conference of the United States Court of Appeals for the Federal Circuit); Monroe Freedman, The Lawyer's Moral Obligation of Justification, 74 TEx. L. Rev. 111 (1995); Monroe Freedman, The Professional Responsibility of the Law Professor: Three Neglected Questions, 39 VAND. L. REV. 275 (1986); Monroe Freedman, Lawyer-Client Confidences Under the A.B.A. Model Rules: Ethical Rules Without Ethical Reason, 3 CRIM. Just. ETHICs, Summer/Fall 1984, at 3; Monroe Freedman, Removal and Discipline of Federal Judges, 31 MERCER L. REV. 681 (1980); Monroe Freedman and Janet Starwood, Prior Restraints on Freedom of Expression by Defendants and Defense Attorneys: Ratio Decendi v. Obiter Dictum, 29 STAN. L. REv. 608 (1977); Monroe Freedman, Advertising and Solicitation by Lawyers: A Proposed Redraft of Canon 2 of the Code of Professional Responsibility, 4 HOFSTRA L. Rev. 183 (1976); Monroe Freedman, Professional Responsibility of the Prosecuting Attorney, 55 GEO. L.J. 1030 (1967). 
Finally, despite the ongoing need for reform of ethical rules and practices, I resent the irresponsible charge that the practice of law is inherently immoral or amoral. For more than half a century I have served as an associate, partner, supervisor, co-counsel, consultant, and mentor alongside countless lawyers who, like me, have found the practice of law to be an exhilarating, gratifying, and essentially moral profession of serving the dignity and autonomy of our fellow citizens and of maintaining the ideals of our constitutional democracy. This moral role of service to others, and to our society, would not be possible if lawyers were to view their relationship with their clients with a patronizing attitude of moral arrogance. 
